Cochrane Database of Systematic Reviews

\title{
Interventions in the management of serum lipids for preventing stroke recurrence (Review)
}

Manktelow BN, Potter JF

Manktelow BN, Potter JF.

Interventions in the management of serum lipids for preventing stroke recurrence.

Cochrane Database of Systematic Reviews 2009, Issue 3. Art. No.: CD002091.

DOI: 10.1002/14651858.CD002091.pub2.

www.cochranelibrary.com 
TABLE OF CONTENTS

ABSTRACT

PLAIN LANGUAGE SUMMARY

BACKGROUN

OBJECTIVES

METHODS

RESULTS

DISCUSSION

AUTHORS' CONCLUSIONS

REFERENCES

CHARACTERISTICS OF STUDIES

DATA AND ANALYSES

Analysis 1.1. Comparison 1 Intervention versus control: history of stroke or TIA, Outcome 1 All ischaemic or haemorrhagic strokes.

Analysis 1.2. Comparison 1 Intervention versus control: history of stroke or TIA, Outcome 2 All-cause mortality, including sudden deaths.

Analysis 1.3. Comparison 1 Intervention versus control: history of stroke or TIA, Outcome 3 Serious vascular events.

Analysis 1.4. Comparison 1 Intervention versus control: history of stroke or TIA, Outcome 4 Ischaemic strokes.

Analysis 1.5. Comparison 1 Intervention versus control: history of stroke or TIA, Outcome 5 Haemorrhagic strokes.

Analysis 2.1. Comparison 2 Intervention versus control: history of stroke, Outcome 1 All ischaemic or haemorrhagic strokes. ..

Analysis 2.2. Comparison 2 Intervention versus control: history of stroke, Outcome 2 All cause mortality, including sudden deaths.

Analysis 2.3. Comparison 2 Intervention versus control: history of stroke, Outcome 3 Serious vascular events.

FEEDBACK

WHAT'S NEW

HISTORY 
[Intervention Review]

\section{Interventions in the management of serum lipids for preventing stroke recurrence}

Bradley N Manktelow ${ }^{1}$, John F Potter 2

1Department of Health Sciences, University of Leicester, Leicester, UK. 2Ageing \& Stroke Medicine, Norwich Medical School, University of East Anglia, Norwich, UK

Contact: Bradley N Manktelow, Department of Health Sciences, University of Leicester, 22-28 Princess Road West, Leicester, LE1 6TP, UK. bm18@leicester.ac.uk.

Editorial group: Cochrane Stroke Group.

Publication status and date: Edited (no change to conclusions), comment added to review, published in Issue 7, 2019.

Citation: Manktelow BN, Potter JF. Interventions in the management of serum lipids for preventing stroke recurrence. Cochrane Database of Systematic Reviews 2009, Issue 3. Art. No.: CD002091. DOI: 10.1002/14651858.CD002091.pub2.

Copyright @ 2019 The Cochrane Collaboration. Published by John Wiley \& Sons, Ltd.

\section{A B S T R A C T}

\section{Background}

Studies have shown that interventions which reduce total and low-density lipoprotein cholesterol levels also reduce coronary heart disease (CHD) and stroke events in those with a history of CHD. However, it is uncertain whether treatment to alter cholesterol levels can prevent recurrence of either stroke or subsequent cardiovascular events and whether differences in outcomes exist between classes of lipidlowering therapy. This is an update of a Cochrane review first published in 2002.

\section{Objectives}

To investigate the effect of altering serum lipids pharmacologically for preventing subsequent cardiovascular disease and stroke recurrence in patients with a history of stroke.

\section{Search methods}

We searched the Cochrane Stroke Group Trials Register (last searched December 2008), the Cochrane Central Register of Controlled Trials (The Cochrane Library Issue 3, 2008), MEDLINE (1966 to December 2008) and EMBASE (1980 to December 2008). We contacted pharmaceutical companies known to produce a lipid-lowering agent for information on relevant publications or unpublished work.

\section{Selection criteria}

Unconfounded randomised trials of participants aged 18 years and over with a history of stroke or transient ischaemic attack (TIA).

\section{Data collection and analysis}

Two review authors independently selected trials, assessed quality and extracted data.

\section{Main results}

We included eight studies involving approximately 10,000 participants. The active interventions were pravastatin, atorvastatin, simvastatin, clofibrate, and conjugated oestrogen. Fixed-effect analysis showed no overall effect on stroke recurrence but statin therapy alone had a marginal benefit in reducing subsequent cerebrovascular events in those with a previous history of stroke or TIA (odds ratio (OR) $0.88,95 \%$ confidence interval ( $\mathrm{Cl}) 0.77$ to 1.00$)$. There was no evidence that such intervention reduced all-cause mortality or sudden death (OR $1.00,95 \% \mathrm{Cl} 0.83$ to 1.20$)$. Three statin trials showed a reduction in subsequent serious vascular events $(\mathrm{OR} 0.74,95 \% \mathrm{Cl} 0.67$ to 0.82$)$. 


\section{Authors' conclusions}

There is evidence that statin therapy in patients with a history of ischaemic stroke or TIA significantly reduces subsequent major coronary events but only marginally reduces the risk of stroke recurrence. There is no clear evidence of beneficial effect from statins in those with previous haemorrhagic stroke and it is unclear whether statins should be started immediately post stroke or later. In view of this and the evidence of the benefit of statin therapy in those with a history of CHD, patients with ischaemic stroke or TIA, with or without a history of established CHD, should receive statins.

\section{PLAIN LANGUAGE SUMMARY}

\section{Interventions in the management of serum lipids for preventing stroke recurrence}

There is evidence of a reduction in subsequent serious vascular events from statin therapy in patients with a history of ischaemic stroke or transient ischaemic attack (TIA). Studies have shown that interventions for reducing either total serum cholesterol or low density lipoprotein cholesterol levels reduce the risk of coronary heart disease (CHD) and stroke events in people with a history of CHD. However, for stroke patients the relation between the level of serum cholesterol and cholesterol subfractions with the risk of future stroke or cardiovascular events is unclear. This review, which includes eight studies involving approximately 10,000 participants, shows statin therapy, but not other lipid-lowering measures, reduces the risk of subsequent major vascular events and a marginal benefit in decreasing stroke events, but not all-cause mortality in those with a history of ischaemic cerebrovascular disease. 


\section{B A C K G R O U N D}

A close association between serum lipid levels and the incidence of coronary heart disease (CHD) has been well proven in middleaged and elderly people. The UK Joint Working Party called the evidence that patients with established CHD benefit from cholesterol reduction "exceptionally strong" and recommended that all patients with established coronary artery disease should have their serum cholesterol reduced to at least below $5.0 \mathrm{mmol} /$ I (Wood 1998). The British Hypertension Society (Williams 2004) and Joint British Society guidelines on prevention of cardiovascular disease (JBS2 2005) make similar recommendations. However, the relation between plasma cholesterol and cholesterol subfractions with cerebrovascular disease is much more controversial. Two meta-analyses of observational data on the relation between serum lipid levels and stroke highlight the uncertainty in the relation between serum lipids and stroke recurrence: one of the studies involved 61 observational cohorts of 900,000 individuals (PSC 2007) and the other 13 cohorts of 125,000 Asian participants (ESCHD 1998). The Prospective Studies Collaborative found no positive association between cholesterol and stroke (including cerebral infarction, cerebral haemorrhage and unclassified stroke) apart from a weak link in those in early middle age (40 to 59 years of age). In the study of Asian populations, no clear relation between cholesterol levels and stroke was found, though there was a trend towards a lower risk of non-haemorrhagic and an increased risk of haemorrhagic stroke with decreasing cholesterol levels.

Direct evidence from randomised trials involving agents that alter serum lipid levels to prevent first-time strokes (i.e. primary stroke prevention) is also lacking (Atkins 1993; Hebert 1995). However, meta-analyses of the accumulated data do suggest that HMG-CoA reductase inhibitors, i.e. statins, may reduce primary stroke incidence (Blauw 1997; Bucher 1998; Byington 2001; Crouse 1997; Di Mascio 2000; Hebert 1997). The Cholesterol Treatment Trialists' Collaboration (CTT 2005) reported a reduction in nonhaemorrhagic stroke incidence with LDL cholesterol reduction but not in haemorrhagic strokes. Other evidence suggests that reducing total serum cholesterol levels may paradoxically increase the risk of a haemorrhagic stroke (Law 2003).

If the relation between serum lipids and primary stroke incidence is unclear, the association between stroke recurrence and serum cholesterol is even more uncertain (McNaughton 2002). There is no consistent evidence available yet as to whether lipid levels post stroke are a risk factor for recurrence and whether treatment to alter levels is of benefit in terms of prevention for either stroke recurrence or any subsequent cardiovascular event. Indeed, there is observational evidence that higher serum cholesterol concentrations in the immediate post-stroke period are associated with increased survival (Dyker 1997; Sandercock 2001; Vauthey 2000). A similar confused picture exists between the relation of blood lipids in the non-acute post-stroke period and stroke recurrence. The mainly cohort studies to date have either taken people who have experienced an unspecified cerebrovascular event (Jorgensen 1997) or included only haemorrhagic strokes (Neau 1997; Passero 1995), while a further group considered minor ischaemic events, including transient ischaemic attacks (TIAs), as well as acute ischaemic strokes (Candelise 1986; Eliasziw 1995; Marshall 1961; Moroney 1997; Prencipe 1998; Sorensen 1989; van Latum 1995). However, there is added confusion in that stroke classification, both initial and subsequent, had not been taken into account and the measures of serum lipid levels differed between reports (i.e. some have used total serum cholesterol, others triglycerides or lipoprotein sub-fraction levels). In addition, some studies have used lipid levels taken in the acute stroke period on which to base the outcome analysis, whereas others have taken measurements made weeks to months after the event. There is evidence that lipid levels in the immediate post-stroke period differ from those taken some weeks after the event, with levels falling in the post-stroke period (Butterworth 1997; Mendez 1987).

It is also unclear from observational studies whether total serum cholesterol levels, cholesterol sub-fractions or triglyceride levels are directly related to cerebrovascular disease or whether they are acting as markers for co-morbid conditions, such as $\mathrm{CHD}$, and that it is the latter that is associated with stroke recurrence, not lipid levels per se.

This is an update of a Cochrane review, first published in 2002, which investigates the effects of the treatments that alter serum lipid levels in patients who have had a cerebral infarct, haemorrhage, minor stroke or TIA with stroke recurrence as an outcome measure, taking into account three recently published trials that have specifically looked at the effects of statin therapy in those with a previous history stroke or TIA.

\section{O B JECTIVES}

To investigate the effects of treatments that alter serum lipid levels in patients who have had a cerebral infarct, haemorrhage, unspecified stroke type, minor stroke or TIA in relation to the outcome measure of stroke recurrence.

\section{METHODS}

\section{Criteria for considering studies for this review \\ Types of studies}

Published or unpublished unconfounded randomised trials of interventions in the treatment of serum lipid levels for the prevention of stroke recurrence.

\section{Types of participants}

Patients over 18 years of age with a history of ischaemic or haemorrhagic stroke, including TIA, who were eligible for randomisation.

\section{Types of interventions}

We investigated all interventions designed to control serum lipid levels. This included drugs (e.g. statins, fibrates, niacin) and diet (e.g. fibre) given at any dose and for any duration. We classified fish oils as either a drug or diet intervention according to the method of administration.

\section{Types of outcome measures}

\section{Primary outcome}

- All ischaemic or haemorrhagic strokes.

\section{Secondary outcomes}

- Fatal and disabling stroke events.

- All-cause mortality, including sudden deaths. 
- Serious vascular events (non-fatal stroke, non-fatal myocardial infarction (MI), vascular death).

- All cardiovascular events (fatal and non-fatal MI, congestive cardiac failure, symptomatic peripheral vascular disease).

\section{Search methods for identification of studies}

See the 'Specialized register' section in the Cochrane Stroke Group module.

We searched the Cochrane Stroke Group Trials Register, which was last searched by the Review Group Co-ordinator in December 2008, the Cochrane Central Register of Controlled Trials (CENTRAL) (The Cochrane Library Issue 3, 2008), MEDLINE (1966 to December 2008) (Appendix 1) and EMBASE (1980 to December 2008). We also contacted the following pharmaceutical companies known to produce a lipid-lowering agent and asked them to provide information on publications or unpublished work relevant to this review.

- Bristol Myers Squibb Pharmaceuticals Ltd (pravastatin, cholestyramine);

- Fournier Pharmaceuticals Ltd (fenofibrate);

- Merck Sharp \& Dohme Ltd (simvastatin);

- Parke-Davis Research Laboratories (atorvastatin, gemfibrozil);

- Pharmacia and Upjohn Ltd (acipimox, colestipol);

- Reckitt and Colman Products Ltd (soluble fibre);

- Roche Products Ltd (bezafibrate);

- Sandoz Pharmaceuticals (fluvastatin);

- Sanofi Winthrop (ciprofibrate);

- Zeneca Pharmaceuticals (clofibrate).

\section{Data collection and analysis}

We independently assessed the trials identified. We obtained the full text of all studies where there was no evidence from the abstract that any of the selection criteria were not met by the study. We then confirmed which trials met the selection criteria, with all decisions on the inclusion of a trial being reached by consensus. If we could not reach agreement, we agreed to seek appropriate external advice for a final decision, although this was not necessary in this review. Where necessary, we contacted study authors for clarification. We also planned to contact study authors if information on the primary outcome was missing; however, this was not necessary.

We recorded details of the methodological quality of the included trials. In particular, we extracted details of randomisation, blinding, and participants withdrawn or lost to follow up. We did not use a scoring system for study quality. We included trials with an inadequate method of randomisation (i.e. where allocation could be anticipated or interfered with) because of the possible identification of older trials that were undertaken prior to currently accepted standards of trial design. However, we planned to perform sensitivity analyses by repeating any analysis excluding these studies, but this was not necessary.

We planned to exclude trials of drug interventions without full concealment of treatment allocation from both patients and clinicians, but we did not identify any such trials. Trials of diet interventions should be blind to any person making outcome assessments. We also planned to exclude confounded trials (i.e. trials where an additional active treatment is administered to one of the groups in a non-factorial design), but we did not identify any such trials.

We carried out data extraction independently, and agreed to resolve any disagreements using the procedure outlined above, but we did not disagree on any aspects of data extraction. We estimated the overall treatment effect by the Peto odds ratio (OR) from a fixed-effect model. We carried out all statistical analysis using the Cochrane Review Manager software, Review Manager 5.0 (RevMan 2008).

If possible, we planned to perform subgroup analyses to investigate the effect of the following.

1. Baseline cerebrovascular disease type:

a. all strokes and TIAs;

b. all acute strokes;

c. all acute ischaemic strokes and TIAs (not done);

d. all acute ischaemic strokes (not done);

e. all haemorrhagic strokes (not done).

2. Intervention type:
a. any drug versus control;
b. statins (any dose) versus control (not done);
c. statins (high dose) versus control (not done);
d. non-statin drugs versus control;
e. diet versus none (not done).

3. Previous cardiovascular event (not done).

4. Optimal cholesterol control versus standard control (not done).

We had planned to perform a meta-regression to investigate the effect of lipid changes actually achieved if unbiased estimates had been obtainable. There was also insufficient information for an assessment of potential side effects from treatment.

\section{RE S U L T S}

\section{Description of studies}

We identified eight trials that met all of the inclusion criteria. Five of the studies investigated statins: pravastatin (CARE; LIPID), simvastatin (HPS; FASTER); and atorvastatin (SPARCL). Two looked at the use of clofibrate (Acheson 1972; VACSA 1973), and the eighth used oestrogen as Premarin (VASCA 1966). However, the data used here from three studies (CARE; LIPID; HPS) are sub-group analyses from the trials.

Of the trials where data from subgroups of the trial population were analysed, one trial only included patients with a history of $\mathrm{MI}$ or unstable angina (LIPID), another only recruited those who had had an acute MI (CARE), whereas the third included adults with coronary disease, other occlusive arterial disease or diabetes (HPS). The remaining trials also differed in their study populations. One study included patients who had experienced a cerebral infarct or TIA (VACSA 1973), whereas another only included those whose symptoms lasted over 12 hours (VASCA 1966). The other trials recruited patients with any history of stroke or TIA as the inclusion event (Acheson 1972; SPARCL), but certain sub-groups of stroke were excluded at entry in some trials, e.g. cardio-embolic strokes in SPARCL. In the FASTER study, statin treatment was started within 24 hours of onset of a minor stroke or TIA. Data on the time from 
stroke onset to randomisation were not reported in the trials but was in the order of several weeks to years. The effect this may have had in terms of outcome measures was also not recorded.

In addition, the studies differed in the length of follow up of the patients. The shortest reported length of follow up was 90 days for the FASTER study, followed by the VASCA trial, with an average follow up of under 17 months (VASCA 1966). This increased to up to four years in one trial (Acheson 1972), and up to four and a half years in another (VACSA 1973). The four more recent trials reported that patients were followed for six years (LIPID, a median of five years (range 4.0 to 6.2 years) (CARE), a median of 4.9 years (SPARCL) and a mean of five years (HPS).

\section{Risk of bias in included studies}

All the trials identified were unconfounded parallel group randomised trials.

It was unclear whether allocation concealment was adequate in two trials (Acheson 1972; VACSA 1973) as details are not reported: neither study used an intention-to-treat analysis. Eleven patients were excluded from the former (Acheson 1972): three because the diagnosis was incorrect and a further eight because they refused to co-operate during the follow-up period. The other trial (VACSA 1973) excluded nine participants; eight were randomised to a hospital not continuing in the study, and one was illegible because of a concurrent malignancy. In neither case was it stated to which treatment group each of these participants had been randomised.

One trial matched patients pairwise according to identified potential risk factors: clinical status, duration of disease, age, sex, degree of hypertension, and serum cholesterol level (within 50 $\mathrm{mg} / 100 \mathrm{ml}$ ) (Acheson 1972).

Another trial reported a slightly higher rate of cardiovascular disorders in the control group at baseline (VASCA 1966) and some differences between the treatment groups were reported in a further study (VACSA 1973), although it is not stated whether these were felt to be clinically important. The final studies (CARE; FASTER; HPS; LIPID; SPARCL) reported that, for the entire study populations in each trial, the two treatment groups were similar with respect to stroke risk factors.

\section{Effects of interventions}

\section{All ischaemic or haemorrhagic strokes}

Seven of the studies reported stroke recurrence as an outcome measure for those with a previous history of stroke or TIA. Overall, using a fixed-effect analysis there was no evidence, at the $5 \%$ significance level, for a difference in outcome between the treatment and placebo groups. There was, however, some evidence of a difference between the two treatment groups (statins and fibrates: $P=0.03$ ).

The treatment effects from the two trials of fibrates tended to favour the control group although this was not statistically significant (odds ratio (OR) 1.48, 95\% confidence interval (CI) 0.94 to 2.30). For the studies involving statins only, there was borderline statistical difference favouring the active treatment group compared with the placebo groups in stroke recurrence (OR $0.88,95 \% \mathrm{Cl} 0.77$ to 1.00 ) (five studies) with no evidence of heterogeneity in the results $(P=0.25)$. However, analysis by type of subsequent stroke (two studies) showed evidence for a protective effect of statins for ischaemic stroke (OR $0.78,95 \% \mathrm{Cl} 0.67$ to 0.92$)$ (Analysis 1.4) but evidence for an increased risk of haemorrhagic stroke (OR 1.72, 95\% Cl 1.20 to 2.46) (Analysis 1.5).

There was also no evidence of a treatment effect on stroke recurrence for those with a previous history of stroke only (OR 0.97 , $95 \% \mathrm{Cl} 0.71$ to 1.31 ) (four studies) and, although both statin studies showed a tendency toward a protective effect (OR $0.73,95 \% \mathrm{Cl} 0.44$ to 1.22), there was no evidence of heterogeneity amongst all of the studies included with the overall results $(P=0.30)$ nor for difference between the type of intervention $(P=0.19)$.

\section{All-cause mortality, including sudden deaths}

Despite the reduction in serious cardiovascular events with statin therapy, there was no evidence that intervention reduced all-cause mortality in patients with a history of stroke or TIA (OR 1.00, 95\% $\mathrm{Cl} 0.83$ to 1.20 ) (Analysis 1.2) (three studies) and no evidence that treatment type influenced this outcome (test for subgroup differences $P=0.52$ ), but this is based on only one trial in the statin group and two in the fibrate group.

For patients with a history of stroke only, OR $1.16,95 \% \mathrm{Cl} 0.69$ to 1.95 (one study).

\section{Serious vascular events}

There was strong evidence for a reduction in subsequent vascular events in patients with a history of stroke or TIA with lipid-lowering therapy: OR $0.77,95 \% \mathrm{Cl} 0.70$ to $0.84, \mathrm{P}<0.0001$ (four studies). This effect was due to the positive results from the two large trials of statins (HPS; SPARCL), though not from the early statin intervention trial (FASTER). For patients with a history of stroke or TIA , subsequent serious vascular events were significantly reduced (OR $0.74,95 \% \mathrm{Cl} 0.67$ to 0.82 ) in those on statins in the three studies where data were available.

For patients with a history of stroke only, the results were only available from a trial of oestrogen where no beneficial effect was seen: OR $1.03,95 \% \mathrm{Cl} 0.72$ to 1.48 .

The effects of treatment on outcome measures could not be calculated in relation to lipid level changes between treatment and control groups for any of the outcome measures. The decision was taken post hoc to analyse the data according to non-statin drug type (i.e. fibrate and oestrogen) where possible. This was done to provide more information but should be interpreted in the light of it being a post hoc decision.

\section{DISCUSSION}

Since publication of the previous Cochrane analysis in 2002, there have been three important trials of the effects of altering lipid levels pharmacologically post stroke on stroke recurrence, development of serious vascular events, and death, all of which have involved the use of statins. The Heart Protection Study (HPS) enrolled 3280 patients aged 40 to 80 years, $64 \%$ with a history of ischaemic stroke and $46 \%$ with TIA (those with cerebral haemorrhage were excluded) and a baseline total cholesterol (TC) $>3.5 \mathrm{mmol} / \mathrm{l}$ with a mean of $5.9 \mathrm{mmol} / \mathrm{l}$. They were randomised to simvastatin $40 \mathrm{mg}$ daily or placebo and followed up for 4.8 years. The SPARCL trial was the first to assess the effects of a statin (atorvastatin $80 \mathrm{mg}$ daily) exclusively in stroke patients, enrolling 4731 participants aged over 18 years 
with cerebral infarction (67\%), TIA (30\%) and cerebral haemorrhage (2\%). Baseline TC was $<5.5 \mathrm{mmol} / \mathrm{l}$ and follow up was for 4.9 years. Most recently the FASTER study was published, having been prematurely stopped because of recruitment problems. This trial recruited minor stroke and TIA patients within 24 hours of symptom onset, of whom 199 patients were randomised to simvastatin $40 \mathrm{mg}$ and 193 to placebo with a 90-day follow up. Overall the trials involving both statins and fibrates failed to demonstrate that therapy reduced stroke recurrence in patients with a history of cerebrovascular disease, although the trials showed some degree of heterogeneity in terms of the outcome measure between the different drug classes.

The two trials that excluded TIA patients, randomising only patients with a history of stroke and CHD, to pravastatin or placebo (CARE; LIPID) similarly failed to offer point estimates of treatment effect favouring the use of statins. However, these were both small subgroup analyses from large trials, and included only 821 patients. The estimated odds ratio for treatment effect had a wide confidence interval (OR $0.73,95 \% \mathrm{Cl} 0.44$ to 1.22 ). However, these two statin-based trials comprised patients who had a history of CHD and who are likely to be prescribed statins to reduce the risk of further heart disease irrespective of their effectiveness in preventing further stroke episodes. These two trials were also limited in their applicability as the study population was aged 75 years or under but did include patients with TIA.

The results from the important HPS study show evidence of benefit from statin therapy in the sub-group of patients with a history of cerebrovascular disease in preventing subsequent major vascular events (i.e. major coronary event and coronary or noncoronary revascularisation) but, interestingly, not stroke. There was evidence that those with a history of cerebrovascular disease were more likely to develop subsequent cerebral haemorrhage with simvastatin than those without a stroke history. However, these data are also limited by the relatively small number of stroke events in this sub-group and that the results apply only to those under the age of 80 years, who have had an ischaemic, but not haemorrhagic, stroke or TIA and who are not severely disabled after their initial stroke. We were unable to differentiate further between stroke subtype, e.g. large artery events versus lacunar and cardio-embolic events, as well as between infarct and haemorrhagic strokes. The effect of statin treatment on major vascular event rates were not reported in the CARE and LIPID studies. No other lipid-lowering trials to date have shown this benefit in study populations, including both those with and without a history of cerebrovascular disease (ALLHAT 2002; PROSPER 2002). The PROSPER Trial (PROSPER 2002) investigated the effects of pravastatin in older people (aged 70 to 82 years) with a history of, or risk factors for, vascular disease (of whom $11 \%$ had a previous stroke) and although it showed evidence of a reduction in the risk of subsequent coronary artery disease there was no evidence of a benefit in stroke reduction (the data relating to those with a history of stroke have not been presented separately). Similarly, major vascular event rates were not reported in the stroke subgroup of the CARE and LIPID studies. The ALLHAT (ALLHAT 2002) and ASCOT (ASCOT 2003) studies also showed no evidence for a reduction in stroke, nor in coronary heart disease, although in this trial the patients in the usual care group experienced an $11 \%$ fall in cholesterol levels. Subgroup analyses from these trials of patients with a previous history of cerebrovascular disease may add further information but are not currently available.
The SPARCL study is unique in that it is the first trial of statins solely in stroke patients without evidence of CHD and included those with a history of cerebral haemorrhage, though the numbers in this group were too small to allow for useful analysis. However, those with presumed cardio-embolic stroke including those with atrial fibrillation were excluded, reducing the generalisability of the results as this might be expected to involve at least $20 \%$ of the stroke population. Non-fatal or fatal stroke were significantly reduced by atorvastatin, though this was mainly due to a reduction in fatal stroke; however, although the odds of ischaemic stroke were reduced by $22 \%$ with atorvastatin, the odds of cerebral haemorrhage were significantly increased by $66 \%$. This is the only study to date that has shown drug induced changes in serum lipids are associated with a reduction in stroke risk. Active treatment also reduced the odds of any coronary event by $42 \%$ and the odds of all major cardiovascular events by $20 \%$.

It is impossible to assess in this review if the effects of time from stroke or TIA onset to treatment influences subsequent events as these data are not available, though the range is large, from weeks to years. The FASTER Trial data, however, may indicate that very early intervention (within 24 hours of symptom onset) with statins following stroke could have an adverse effect, there being a nonsignificant increase in stroke recurrence for the simvastatin-treated patients; this needs further clarification.

Amongst the eight trials that have aimed to alter lipid levels following stroke or TIA, three different classes of drugs have been used: the majority have used statins (CARE; FASTER; HPS; LIPID; SPARCL); two used fibrates (Acheson 1972; VACSA 1973) and one oestrogen (VASCA 1966). However, because of the way the data are presented it is difficult to directly compare outcome measures between trials for all stroke events (the outcome measure where most information is available). There was some evidence for differences in outcome between drug groups: statin therapy resulting in a borderline significant $12 \%$ reduction in the odds of subsequent cerebrovascular events compared to a $48 \%$ increase in odds with fibrates. Even in the statin trials, there was a diversity of effect on stroke sub-type, with a significant $72 \%$ increase in the odds of cerebral haemorrhage with treatment which partially offset the $22 \%$ reduction in odds for ischaemic stroke (there being a 10:1 ratio of ischaemic to haemorrhagic events as would be expected). For serious vascular events, a similar difference was seen between statins and fibrates, although the numbers are much smaller than for stroke recurrence; again statins resulted in a $26 \%$ reduction in the odds compared with a $27 \%$ increase with fibrates, although data were limited to the VACSA trial for the latter drug group. It was not possible to assess if these effects were similar for those who had a previous history of stroke only as opposed to TIA: the data from trials that enrolled only stroke patients, as opposed to those with recruiting either stroke or TIA, appear not to differ in outcomes. Statin therapy, however, appeared to have no benefit in reducing all-cause mortality.

It is not possible to obtain sufficient data on baseline lipid levels or the size of the lipid changes achieved during any of the trials in relation to outcomes. This would be useful information in order to investigate whether the potential neuroprotective effects of statins derive solely from their lipid-altering effects or by some other mechanisms, e.g. anti-inflammatory effects or endothelial protection. Some information on the recorded blood pressures of the patients and other potential risk factors for stroke recurrence, 
as well as other secondary preventative measures such as aspirin use, would also have been of interest.

Many important questions are still left unanswered regarding lipidaltering therapy in the post-stroke period. It was not possible to assess the effects of any of the lipid agents on those with a previous cerebral haemorrhage (the numbers in the SPARCL study were too small and not reported separately) or TIA. It is unclear when after the cerebrovascular event therapy to alter lipid levels should be started, at what baseline lipid levels treatment should be commenced, what level of reduction should be aimed for or whether the very elderly (those aged over 80 years) stroke patient benefits to the same extent as a younger counterpart.

\section{AUTHORS' CONCLUSIONS}

\section{Implications for practice}

There is good evidence for a benefit of statin therapy in those under the age of 80 years with a previous non-disabling stroke or TIA (but not cerebral haemorrhage) who have baseline total cholesterol levels $>3.5 \mathrm{mmols} / \mathrm{l}$ in terms of reducing subsequent serious vascular events. The data also suggest a marginal benefit of statins in reducing future cerebrovascular events, but not overall mortality. In view of this evidence it is recommended that all ischaemic stroke or TIA patients aged at least up to 80 years should receive statin therapy as part of a secondary prevention programme

\section{Implications for research}

Further work is needed to assess the potential role of statins for those patients with a previous cerebral haemorrhage, when after the cerebrovascular event therapy to alter lipid levels should be started, at what baseline lipid levels treatment should be commenced, what level of reduction should be aimed for or whether the very elderly (those aged over 80 years) stroke patient benefits to the same extent as a younger counterpart. 


\section{RE F E R E N C E S}

\section{References to studies included in this review}

\section{Acheson 1972 \{published data only\}}

Acheson J, Hutchinson EC. A controlled trial of atromid in cerebral vascular disease. A preliminary report. Journal of Atherosclerosis Research 1963;3:711-5.

* Acheson J, Hutchinson EC. Controlled trial of clofibrate in cerebral vascular disease. Atherosclerosis 1972;15:177-83.

\section{CARE \{published data only\}}

* Plehn JF, Davis BR, Sacks FM, Rouleau JL, Pfeffer MA, Bernstein V, et al. Reduction of stroke incidence after myocardial infarction with pravastatin: the Cholesterol and Recurrent Events (CARE) Study. Circulation 1999;99(2):216-23. [MEDLINE: 99110724]

Sacks FM, Pfeffer MA, Moye L, Brown LE, Hamm P, Cole TG, et al. Rationale and design of a secondary prevention trial of lowering normal plasma cholesterol levels after acute myocardial infarction: the Cholesterol and Recurrent Events Trial (CARE). American Journal of Cardiology 1991;68:1436-46.

Sacks FM, Pfeffer MA, Moye LA, Rouleau JL, Rutherford JD, Cole TG, et al. The effect of pravastatin on coronary events after myocardial infarction in patients with average cholesterol levels. New England Journal of Medicine 1996;335:1001-9.

\section{FASTER \{published data only\}}

Kennedy J, Eliasziw M, Hill MD, Buchan AM. The Fast Assessment of Stroke and Transient Ischemic Attack to Prevent Early Recurrence (FASTER) Trial. Seminars in Cerebrovascular Diseases and Stroke 2003;3(1):25-30.

* Kennedy J, Hill MD, Ryckborst KJ, Eliasziw M, Demchuk AM, Buchan AM. Fast assessment of stroke and transient ischaemic attack to prevent early recurrence (FASTER): a randomised controlled pilot trial. Lancet Neurology 2007;6:961-9.

\section{HPS \{published data only\}}

MRC/BHF Heart Protection Study. http://www.ctsu.ox.ac.uk/ hps/.

Collins R, Peto R. MRC/BHF Heart Protection Study. Stroke 1994;25(2):543.

* Heart Protection Study Collaborative Group. Effects of cholesterol-lowering with simvastatin on stroke and other major vascular events in 20,536 people with cerebrovascular disease or other high-risk conditions. Lancet 2004;363:757-67.

Heart Protection Study Collaborative Group. MRC/BHF Heart Protection Study of cholesterol lowering with simvastatin in 20,536 high-risk individuals: a randomised placebo-controlled trial. Lancet 2002;360:7-22.

Heart Protection Study Collaborative Group. The MRC/BHF Heart Protection Study: preliminary results. International Journal of Clinical Practice 2002;56(1):53-6.
MRC/BHF Heart Protection Study. MRC/BHF Heart Protection Study of cholesterol-lowering therapy and of antioxidant vitamin supplementation in a wide range of patients at increased risk of coronary heart disease death: early safety and efficacy experence. European Heart Journal 1999;20:725-41.

LIPID \{published data only\}

Kirby A. Personal communication. Unpublished.

The LIPID Study Group. Long-term effectiveness and safety of pravastatin in 9014 patients with coronary heart disease and average cholesterol concentrations: the LIPID trial follow-up. Lancet 2002;359:1379-87.

* White HD, Simes J, Anderson NE, Hankey GJ, Watson JDG, Hunt $D$, et al. Pravastatin therapy and the risk of stroke. New England Journal of Medicine 2000;343(5):317-26.

SPARCL \{published data only\}

Amarenco P, Bogousslavsky J, Callahan A, Goldstein L, Hennerici M, Sillesen $\mathrm{H}$, et al. Effect of atorvastatin compared with placebo on cerebrovascular end points in patients with previous stroke or transient ischemic attack - The SPARCL Study. Cerebrovascular Diseases 1999;9 Suppl 1:108.

SPARCL Investigators. Design and baseline characteristics of the Stroke Prevention by Aggressive Reduction in Cholesterol Levels (SPARCL) study. Cerebrovascular Diseases 2003;16:389-95.

* SPARCL Investigators. High-dose atorvastatin after stroke or transient ischemic attack. New England Journal of Medicine 2006;355(6):549-59. [MEDLINE: 16899775]

Welch KMA. Stroke prevention by aggresive reduction in cholesterol levels (SPARCL). Stroke 2000;31(11):2541.

VACSA 1973 \{published data only\}

Hirsch SB, Wechsler AF, Tourtellotte WW. Clofibrate for the treatment of occlusive cerebrovascular disease. New England Journal of Medicine 1972;287(13):671. [MEDLINE: 73015139]

* The Veterans Administration Cooperative Study Group. The treatment of cerebrovascular disease with clofibrate. Final report of the Veterans Administration Cooperative Study of Atherosclerosis, Neurology Section. Stroke 1973;4:684-93. [MEDLINE: 73232915]

VASCA 1966 \{published data only\}

The Veterans Administration Cooperative Study of Atherosclerosis. An evaluation of estrogenic substances in the treatment of cerebral vascular disease. Circulation 1966;33(5 Suppl):II3-9. [MEDLINE: 91029891]

\section{References to ongoing studies}

\section{J-STARS \{published data only\}}

Kohriyama T, Nomura E, Matsumoto M, Ohtsuki T. J-STARS (Japan Statin Treatment Against Recurrent Stroke). Nippon Rinsho - Japanese Journal of Clinical Medicine 2006;64 Suppl 7:511-8. 


\section{Additional references}

\section{ALLHAT 2002}

ALLHAT Collaborative Research Group. Major cardiovascular events in hypertensive patients randomized to doxazosin vs chlorthalidone: The Antihypertensive and Lipid-Lowering Treatment to Prevent Heart Attack Trial (ALLHAT). Journal of the American Medical Association 2002;288(23):2998-3007.

\section{ASCOT 2003}

Sever PS, Dahlof B, Poulter NR, for the ASCOT investigators. Prevention of coronary and stroke events with atorvastatin in hypertensive patients who have average or lower-than-average cholesterol concentrations, in the Anglo-Scandinavian Cardiac Outcomes Trial - Lipid Lowering Arm (ASCOT-LLA): a multicentre randomized controlled trial. Lancet 2003;361:1149-58.

\section{Atkins 1993}

Atkins D, Psaty BM, Koepsell TD, Longstreth WT, Larson EB. Cholesterol reduction and the risk for stroke in men. A metaanalysis of randomized, controlled trials. Annals of Internal Medicine 1993;199(2):136-45. [MEDLINE: 93290061]

\section{Blauw 1997}

Blauw GJ, Lagaay AM, Smelt AHM, Westendorp RGJ. Stroke, statins, and cholesterol. A meta-analysis of randomized, placebo-controlled, double-blind trials with HMG-COA reductase inhibitors. Stroke 1997;28(5):946-50. [MEDLINE: 97302269]

\section{Bucher 1998}

Bucher HC, Griffith LE, Guyatt GH. Effect of HMGcoA reductase inhibitors on stroke: a meta-analysis of randomized, controlled trials. Annals of Internal Medicine 1998;128(2):89-95. [MEDLINE: 98085833]

\section{Butterworth 1997}

Butterworth RJ, Marshall WJ, Bath PMW. Changes in serum lipid measurements following acute ischemic stroke. Cerebrovascular Diseases 1997;7:10-3.

\section{Byington 2001}

Byington RP, Davis BR, Plehn JF, White HD, Baker J, Cobbe SM, et al. Reduction of stroke events with Pravastatin: the Prospective Pravastatin Pooling (PPP) Project. Circulation 2001;103(3):387-92.

\section{Candelise 1986}

Candelise L, Vigotti M, Fieschi C, Brambilla GL, Bono G, Conforti $\mathrm{P}$, et al. Italian multicenter study on reversible cerebral ischemic attacks: $\mathrm{VI}$ - prognostic factors and follow-up results. Stroke 1986;17(5):842-8. [MEDLINE: 87020005]

\section{Crouse 1997}

Crouse JR 3rd, Byington RP, Hoen HM, Furberg CD. Reductase inhibitor monotherapy and stroke prevention. Archives of Internal Medicine 1997;157(12):1305-10. [MEDLINE: 97344622]

\section{CTT 2005}

Cholesterol Treatment Trialists' (CTT) Collaboration. Efficacy and safety of cholesterol-lowering treatment: prospective metaanalysis of data from 90,056 participants in 14 randomised trials of statins. Lancet 2005;366:1267-78. [MEDLINE: 95282720]

\section{Di Mascio 2000}

Di Mascio R, Marchioli R, Tognoni G. Cholesterol reduction and stroke occurrence: an overview of randomized clinical trials. Cerebrovacular Diseases 2000;10:85-92.

\section{Dyker 1997}

Dyker AG, Weir CJ, Lees KR. Influence of cholesterol on survival after stroke: retrospective study. BMJ 1997;314:1584-8. [MEDLINE: 97329696]

\section{Eliasziw 1995}

Eliasziw M, Streifler JY, Spence JD, Fox AJ, Hachinski VC, Barnett HJM. Prognosis for patients following a transient ischemic attack with and without a cerebral infarction on brain CT. Neurology 1995;45:428-31. [MEDLINE: 95206518]

\section{ESCHD 1998}

Eastern Stroke and Coronary Heart Disease Collaborative Research Group. Blood pressure, cholesterol, and stroke in eastern Asia. Lancet 1998;352:1801-7.

\section{Hebert 1995}

Hebert PR, Gaziano JM, Hennekens CH. An overview of trials of cholesterol lowering and risk of stroke. Archives of Internal Medicine 1995;155(1):50-5. [MEDLINE: 95100811]

\section{Hebert 1997}

Hebert PR, Gaziano JM, Chan KS, Hennekens CH. Cholesterol lowering with statin drugs, risk of stroke, and total mortality. An overview of randomized trials. Journal of the American Medical Association 1997;278(4):313-21. [MEDLINE: 97372174]

\section{JBS2 2005}

British Cardiac Society, British Hypertension Society, Diabetes UK, HEART UK, Primary Care Cardiovascular Society, Stroke Association. JBS 2: Joint British Societies' guidelines on prevention of cardiovascular disease in clinical practice. Heart 2005;91 Suppl 5:v1-52.

\section{Jorgensen 1997}

Jorgensen HS, Nakayama H, Reith J, Raaschou HO, Olsen TS. Stroke recurrence: predictors, severity, and prognosis. The Copenhagen Stroke Study. Neurology 1997;48:891-5. [MEDLINE: 97264001]

\section{Law 2003}

Law MR, Wald NJ, Rudnicka AR. Quantifying effect of statins on low density lipoprotein cholesterol, ischaemic heart disease, and stroke: systematic review and meta-analysis. $B M J$ 2004;326:1423-9.

\section{Marshall 1961}

Marshall J, Kaeser AC. Survival after non-haemorrhagic cerebrovascular accidents: a prospective study. British Medical Journal 1961:73-7. 


\section{McNaughton 2002}

McNaughton $\mathrm{H}$. Lowering lipids after a stroke or transient ischaemic attack. Hospital Medicine 2002;63(2):88-91.

\section{Mendez 1987}

Mendez I, Hachinski V, Wolfe B. Serum lipids after stroke. Neurology 1987;37:507-11. [MEDLINE: 87145065]

\section{Moroney 1997}

Moroney JT, Bagiella E, Tatemichi TK, Paik MC, Stern Y, Desmond DW. Dementia after stroke increases the risk of longterm stroke recurrence. Neurology 1997;48:1317-25. [MEDLINE: 97297833]

\section{Neau 1997}

Neau J-P, Ingrand P, Couderq C, Rosier MP, Bailbe M, Dumas P, et al. Recurrent intracerebral hemorrhage. Neurology 1997;49:106-13. [MEDLINE: 97365340]

\section{Passero 1995}

Passero S, Burgalassi L, D'Andrea P, Battistini N. Recurrence of bleeding in patients with primary intracerebral hemorrhage. Stroke 1995;26(7):1189-92. [MEDLINE: 95328103]

\section{Prencipe 1998}

Prencipe M, Culasso F, Rasura M, Anzini A, Beccia M, Cao M, et al. Long-term prognosis after a minor stroke. 10-year mortality and major stroke recurrence rates in a hospital-based cohort. Stroke 1998;29:126-32. [MEDLINE: 98106118]

\section{PROSPER 2002}

Shepherd J, Blauw GJ, Murphy MB, Bollen ELEM, Buckley BM, Cobbe SM, et al. Pravastatin in elderly individuals at risk of vascular disease (PROSPER): a randomised controlled trial. Lancet 2002;360:1623-30.

\section{PSC 2007}

Prospective Studies Collaboration. Blood cholesterol and vascular mortality by age, sex, and blood pressure: a metaanalysis of individual data from 61 prospective studies with 55000 vascular deaths. Lancet 2007;370:1829-39.

\section{RevMan 2008 [Computer program]}

The Nordic Cochrane Centre. The Cochrane Collaboration. Review Manager (RevMan). Version 5.0. Copenhagen: The Nordic Cochrane Centre. The Cochrane Collaboration, 2008.

\section{CHARACTERISTICS OF STUDIES}

Characteristics of included studies [ordered by study ID]

\section{Sandercock 2001}

Sandercock P. Statins for stroke prevention?. Lancet 2001;357:1548-9.

\section{Sorensen 1989}

Sorensen PS, Marquardsen J, Pedersen H, Heltberg A, Munck O. Long-term prognosis and quality of life after reversible cerebral ischemic attacks. Acta Neurologica Scandinavica 1989;79:204-13. [MEDLINE: 89244104]

\section{van Latum 1995}

van Latum JC, Koudstaal PJ, Venables GS, van Gijn J, Kappelle LJ, Algra A. Predictors of major vascular events in patients with a transient ischemic attack or minor ischemic stroke and with nonrheumatic atrial fibrillation. Stroke 1995;26(5):801-6. [MEDLINE: 95259107]

\section{Vauthey 2000}

Vauthey C, de Freitas GR, van Melle G, Devuyst G, Bogousslavsky J. Better outcome after stroke with higher serum cholesterol levels. Neurology 2000;54(10):1944-9.

\section{Williams 2004}

Williams B, Poulter NR, Brown MJ, Davis M, McInnes GT, Potter JF, et al. Guidelines for management of hypertension: report of the fourth working party of the British Hypertension Society, 2004 - BHS IV. Journal of Human Hypertension 2004;18(3):139-85.

\section{Wood 1998}

Wood D, Durrington P, McInnes, Paulter N, Rees A, Wray R. Joint British recommendations on prevention of coronary heart disease in clinical practice. Heart 1998;80 Suppl 2:S1-29.

\section{References to other published versions of this review \\ Manktelow 2002}

Manktelow BN, Gillies C, Potter J. Interventions in the management of serum lipids for preventing stroke recurrence. Cochrane Database of Systematic Reviews 2002, Issue 3. [Art. No.: CD002091. DOI: 10.1002/14651858.CD002091]

* Indicates the major publication for the study

Acheson 1972

\begin{tabular}{ll}
\hline Methods & Parallel group, placebo-controlled trial \\
\hline Participants & 106 patients (11 excluded from analysis: 3 incorrect diagnosis; 8 refused to co-operate) \\
& Country: UK \\
& Study years: 1962 to 1969 \\
& Age: 43 to 76 years \\
& Male: $68 \%$
\end{tabular}


Acheson 1972 (Continued)

Inclusion: previous stroke or TIA

$\begin{array}{ll}\text { Interventions } & \text { Clofibrate ( } 250 \mathrm{mg} \text { capsules: } 4 \text { to } 6 \text { daily for females; } 6 \text { to } 8 \text { daily for males) } \\ & \text { Placebo (corn oil for first } 20 \text { months of trial) }\end{array}$

Follow up: between 4 months and 4 years

\begin{tabular}{ll}
\hline Outcomes & Cerebral ischaemia \\
& Stroke \\
& Mortality \\
\hline Notes & Matched pairs design \\
\hline
\end{tabular}

\section{Risk of bias}

\begin{tabular}{lll}
\hline Bias & Authors' judgement & Support for judgement \\
\hline $\begin{array}{l}\text { Allocation concealment } \\
\text { (selection bias) }\end{array}$ & Unclear risk & B - Unclear \\
\hline
\end{tabular}

\section{CARE}

\begin{tabular}{|c|c|c|}
\hline Methods & \multicolumn{2}{|c|}{ Parallel group, placebo-controlled trial } \\
\hline Participants & \multicolumn{2}{|c|}{$\begin{array}{l}4159 \text { patients (122 previous stroke: } 211 \text { previous stroke or TIA) } \\
\text { Country: USA } \\
\text { Study years: } 1989 \text { to } 1996 \\
\text { Age: } 21 \text { to } 75 \text { years } \\
\text { Male: } 86 \% \text { (whole trial) } \\
\text { Inclusion: MI } 3 \text { to } 20 \mathrm{months} \text { before randomisation, total cholesterol < } 240 \mathrm{mg} / \mathrm{dl} \text {; LDL } 115 \text { to } 174 \mathrm{mg} \text { / } \\
\text { dl; triglycerides } \leq 350 \mathrm{mg} / \mathrm{dl}\end{array}$} \\
\hline Interventions & \multicolumn{2}{|c|}{$\begin{array}{l}\text { Pravastatin }(40 \mathrm{mg} / \mathrm{d}) \\
\text { Matching placebo } \\
\text { Follow up: median } 5.0 \text { years (range } 4.0 \text { to } 6.2 \text { ) }\end{array}$} \\
\hline Outcomes & \multicolumn{2}{|c|}{ Stroke symptoms lasting $\geq 24$ hours } \\
\hline Notes & \multicolumn{2}{|c|}{ Sub-group analysis of trial } \\
\hline \multicolumn{3}{|l|}{ Risk of bias } \\
\hline Bias & Authors' judgement & Support for judgement \\
\hline $\begin{array}{l}\text { Allocation concealment } \\
\text { (selection bias) }\end{array}$ & Low risk & A - Adequate \\
\hline
\end{tabular}

\section{FASTER}

\begin{tabular}{ll}
\hline Methods & Parallel group, placebo-controlled trial \\
& $2 \times 2$ factorial design with clopidogrel \\
\hline Participants & 392 patients \\
& Country: Canada \\
& Study years: 2003 to 2006 \\
\hline
\end{tabular}


FASTER (Continued)

Age: 40 years or older

Male: $53 \%$

Inclusion: TIA or minor stroke (NIHSS < 4) within 24 hours of onset

\begin{tabular}{ll}
\hline Interventions & $\begin{array}{l}\text { Simvastatin }(40 \mathrm{mg} / \mathrm{d}) \\
\text { Matching placebo }\end{array}$ \\
\hline Outcomes & $\begin{array}{l}\text { Stroke within } 90 \text { days } \\
\text { Major vascular event }\end{array}$ \\
\hline Notes & Trial stopped early because of low recruitment
\end{tabular}

\section{Risk of bias}

\begin{tabular}{lll}
\hline Bias & Authors' judgement & Support for judgement \\
\hline $\begin{array}{l}\text { Allocation concealment } \\
\text { (selection bias) }\end{array}$ & Low risk & A - Adequate \\
\hline
\end{tabular}

HPS

$\begin{array}{ll}\text { Methods } & \text { Parallel group, placebo-controlled trial } \\ 2 \times 2 \text { factorial design with antioxidant vitamin supplementation }\end{array}$

20,536 patients (3280 with previous cerebrovascular event)
Country: UK
Study years: 1994 to 2001
Age: around 40 to 80 years
Inclusion: non-fasting total cholesterol $\geq 135 \mathrm{mg} / \mathrm{dL}$, substantial 5-year risk from CHD

\begin{tabular}{ll}
\hline Interventions & $\begin{array}{l}\text { Simvastatin }(40 \mathrm{mg} / \mathrm{d}) \\
\text { Matching placebo }\end{array}$ \\
\hline Outcomes & $\begin{array}{l}\text { Stroke } \\
\text { Major cerebrovascular event }\end{array}$ \\
\hline Notes & Sub-group analysis of $2 \times 2$ factorial design trial \\
\hline
\end{tabular}

\section{Risk of bias}

\begin{tabular}{lll}
\hline Bias & Authors' judgement & Support for judgement \\
\hline $\begin{array}{l}\text { Allocation concealment } \\
\text { (selection bias) }\end{array}$ & Low risk & A-Adequate \\
\hline
\end{tabular}

LIPID

\begin{tabular}{ll}
\hline Methods & Parallel group, placebo-controlled trial \\
\hline Participants & 9014 patients (369 with previous stroke) \\
& Country: Australia and New Zealand \\
Study years: 1990 to 1996 \\
Age: 31 to 75 years \\
Male: $83 \%$
\end{tabular}


LIPID (Continued)

Inclusion: MI or unstable angina pectoris 3 to 36 months before randomisation; total cholesterol 155 to

$271 \mathrm{mg} / \mathrm{dl}$ and fasting triglicerides $<445 \mathrm{mg} / \mathrm{dl}$

\begin{tabular}{ll}
\hline Interventions & $\begin{array}{l}\text { Pravastatin }(40 \mathrm{mg} / \mathrm{d}) \\
\text { Matching placebo } \\
\text { Follow up: } 6 \text { years }\end{array}$ \\
\hline Outcomes & Stroke \\
\hline Notes & Sub-group analysis of trial \\
\hline
\end{tabular}

\section{Risk of bias}

\begin{tabular}{lll}
\hline Bias & Authors' judgement & Support for judgement \\
\hline $\begin{array}{l}\text { Allocation concealment } \\
\text { (selection bias) }\end{array}$ & Low risk & A-Adequate \\
\hline
\end{tabular}

SPARCL

\begin{tabular}{ll}
\hline Methods & Parallel group, placebo-controlled trial \\
\hline Participants & $\begin{array}{l}4731 \text { patients } \\
\text { Country: worldwide (205 sites) } \\
\text { Study years: } 1998 \text { to } 2001 \\
\text { Age: over 18 } \\
\text { Male: } 59.8 \% \\
\text { Inclusion: stroke or TIA in previous } 6 \text { months }\end{array}$ \\
\hline Interventions & $\begin{array}{l}\text { Atorvastatin (80 mg/d) } \\
\text { Matching placebo } \\
\text { Follow up: median 4.9 years }\end{array}$ \\
\hline Outcomes & Fatal or non-fatal stroke \\
\hline Notes & Authors' judgement Support for judgement \\
\hline Risk of bias & Low risk Adequate \\
\hline Bias & \\
\hline $\begin{array}{l}\text { Allocation concealment } \\
\text { (selection bias) }\end{array}$ \\
\hline
\end{tabular}

VACSA 1973

\begin{tabular}{ll} 
Methods & Parallel group, placebo-controlled trial \\
\hline Participants & 541 patients ( 9 excluded from analysis: 8 hospital withdrew; 1 concurrent malignancy) \\
& Country: USA \\
& Study years: 1966 to 1970 \\
& Age: 70 or under \\
Male: $100 \%$
\end{tabular}


VACSA 1973 (Continued)

Inclusion: history of cerebral infarction or TIA

\begin{tabular}{ll}
\hline Interventions & Clofibrate (500 $\mathrm{mg} \times 4$ daily) \\
& Matching placebo \\
& Follow up: up to 4.5 years \\
\hline Outcomes & Mortality \\
& Cerebral infarction \\
& Vascular event \\
\hline
\end{tabular}

Notes

\section{Risk of bias}

\begin{tabular}{lll}
\hline Bias & Authors' judgement & Support for judgement \\
\hline $\begin{array}{l}\text { Allocation concealment } \\
\text { (selection bias) }\end{array}$ & Unclear risk & B - Unclear \\
\hline
\end{tabular}

\section{VASCA 1966}

\begin{tabular}{|c|c|}
\hline Methods & Parallel group, placebo-controlled trial \\
\hline Participants & $\begin{array}{l}582 \text { patients } \\
\text { Country: USA } \\
\text { Study years: } 1962 \text { to } 1965 \\
\text { Age: not known } \\
\text { Male: } 100 \% \\
\text { Inclusion: history of cerebral infarct with symptoms lasting at least } 12 \text { hours }\end{array}$ \\
\hline Interventions & $\begin{array}{l}\text { Mixed conjugated equine oestrogen (Premarin) (1.25 mg daily for } 12 \text { months then } 2.5 \mathrm{mg} \text { ) } \\
\text { Matching placebo } \\
\text { Follow up: average } 16.7 \text { months }\end{array}$ \\
\hline Outcomes & $\begin{array}{l}\text { Cerebral infarct } \\
\text { Cerebral infarct \& MI } \\
\text { All cause mortality }\end{array}$ \\
\hline \multicolumn{2}{|l|}{ Notes } \\
\hline \multicolumn{2}{|l|}{ Risk of bias } \\
\hline Bias & Authors' judgement Support for judgement \\
\hline $\begin{array}{l}\text { Allocation concealment } \\
\text { (selection bias) }\end{array}$ & A - Adequate \\
\hline
\end{tabular}

CHD: coronary heart disease

MI: myocardial infarction

NIHSS: National Institutes of Health Stroke Scale

TIA: transient ischaemic attack

Characteristics of ongoing studies [ordered by study ID] 


\begin{tabular}{ll}
\hline Trial name or title & Japan Statin Treatment Against Recurrent Stroke \\
\hline Methods & $\begin{array}{l}\text { Ischaemic stroke, hyperlipidemia and total cholesterol } 180 \text { to } 240 \mathrm{mg} / \mathrm{dL}, \text { without statin in last } 30 \\
\text { days } \\
\text { Age: } 45 \text { to } 80 \text { years }\end{array}$ \\
\hline Participants & Pravastatin 10 mg/day or placebo \\
\hline Interventions & $\begin{array}{l}\text { Primary: cerebrovascular events } \\
\text { Secondary: stoke subtype, cardiovascular event, stroke death, cerebrovascular and cardiovascular } \\
\text { death }\end{array}$ \\
\hline Starting date & $\begin{array}{l}1 \text { March 2004 } \\
\text { Contact information }\end{array}$ \\
\hline Dotes & mack@hiroshima-u.ac.jp \\
\hline
\end{tabular}

\section{DATA AND ANALYSES}

\section{Comparison 1. Intervention versus control: history of stroke or TIA}

\begin{tabular}{|c|c|c|c|c|}
\hline $\begin{array}{l}\text { Outcome or subgroup } \\
\text { title }\end{array}$ & No. of studies & $\begin{array}{l}\text { No. of partici- } \\
\text { pants }\end{array}$ & Statistical method & Effect size \\
\hline $\begin{array}{l}1 \text { All ischaemic or haem- } \\
\text { orrhagic strokes }\end{array}$ & 7 & 9851 & Peto Odds Ratio (Peto, Fixed, 95\% Cl) & $0.92[0.81,1.04]$ \\
\hline 1.1 Statins & 5 & 9224 & Peto Odds Ratio (Peto, Fixed, 95\% Cl) & $0.88[0.77,1.00]$ \\
\hline 1.2 Fibrates & 2 & 627 & Peto Odds Ratio (Peto, Fixed, 95\% Cl) & $1.48[0.94,2.30]$ \\
\hline $\begin{array}{l}2 \text { All-cause mortality, in- } \\
\text { cluding sudden deaths }\end{array}$ & 3 & 5358 & Peto Odds Ratio (Peto, Fixed, 95\% Cl) & $1.00[0.83,1.20]$ \\
\hline 2.1 Statins & 1 & 4731 & Peto Odds Ratio (Peto, Fixed, 95\% Cl) & $1.03[0.84,1.25]$ \\
\hline 2.2 Fibrates & 2 & 627 & Peto Odds Ratio (Peto, Fixed, 95\% Cl) & $0.87[0.55,1.39]$ \\
\hline 3 Serious vascular events & 4 & 8935 & Peto Odds Ratio (Peto, Fixed, 95\% Cl) & $0.77[0.70,0.84]$ \\
\hline 3.1 Statins & 3 & 8403 & Peto Odds Ratio (Peto, Fixed, 95\% Cl) & $0.74[0.67,0.82]$ \\
\hline 3.2 Fibrates & 1 & 532 & Peto Odds Ratio (Peto, Fixed, 95\% Cl) & $1.27[0.84,1.89]$ \\
\hline 4 Ischaemic strokes & 2 & 8011 & Peto Odds Ratio (Peto, Fixed, 95\% Cl) & $0.78[0.67,0.92]$ \\
\hline 5 Haemorrhagic strokes & 2 & 8011 & Peto Odds Ratio (Peto, Fixed, 95\% Cl) & $1.72[1.20,2.46]$ \\
\hline
\end{tabular}


Analysis 1.1. Comparison 1 Intervention versus control: history of stroke or TIA, Outcome 1 All ischaemic or haemorrhagic strokes.

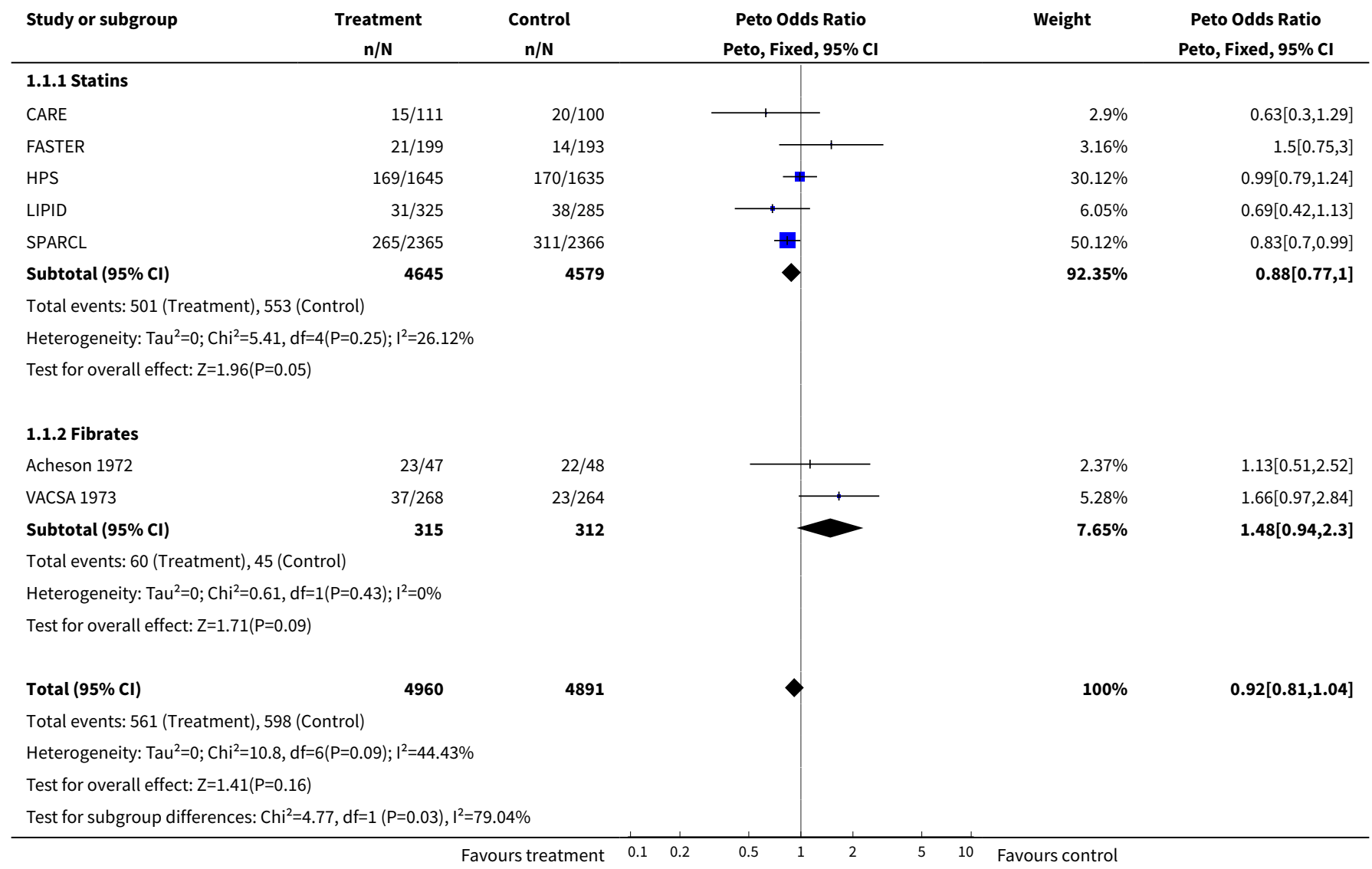

Analysis 1.2. Comparison 1 Intervention versus control: history of stroke or TIA, Outcome 2 All-cause mortality, including sudden deaths.

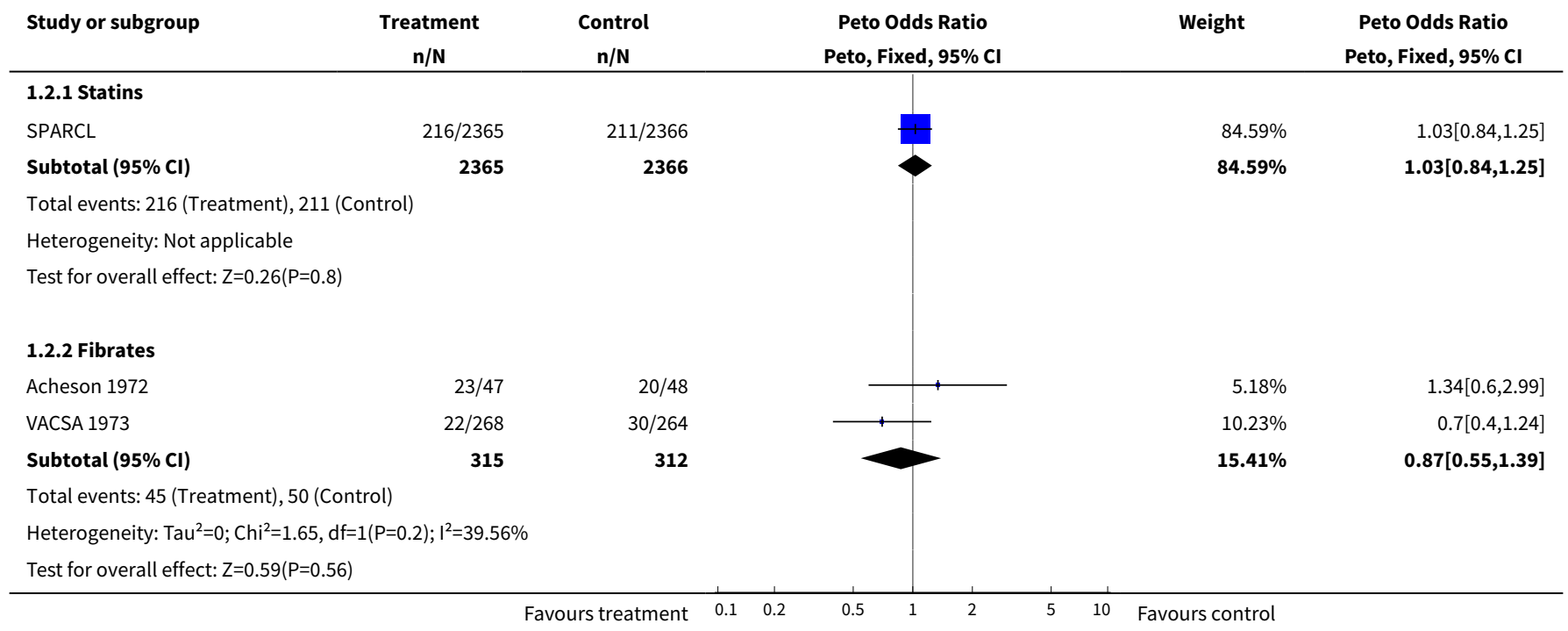




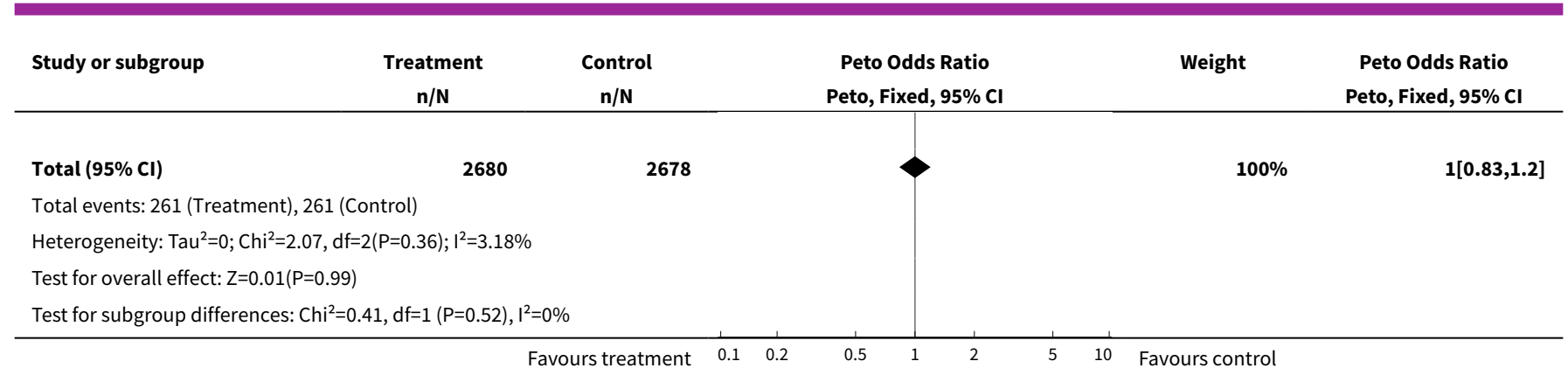

Analysis 1.3. Comparison 1 Intervention versus control: history of stroke or TIA, Outcome 3 Serious vascular events.

\begin{tabular}{|c|c|c|c|c|c|}
\hline Study or subgroup & $\begin{array}{c}\text { Treatment } \\
\mathrm{n} / \mathrm{N}\end{array}$ & $\begin{array}{c}\text { Control } \\
n / N\end{array}$ & $\begin{array}{c}\text { Peto Odds Ratio } \\
\text { Peto, Fixed, } 95 \% \mathrm{Cl}\end{array}$ & Weight & $\begin{array}{c}\text { Peto Odds Ratio } \\
\text { Peto, Fixed, } 95 \% \mathrm{Cl}\end{array}$ \\
\hline \multicolumn{6}{|l|}{ 1.3.1 Statins } \\
\hline FASTER & 23/199 & $17 / 193$ & $\longrightarrow$ & $2.14 \%$ & $1.35[0.7,2.59]$ \\
\hline HPS & $406 / 1645$ & $488 / 1635$ & 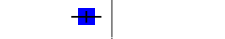 & $38.61 \%$ & $0.77[0.66,0.9]$ \\
\hline SPARCL & $530 / 2365$ & $687 / 2366$ & 里 & $53.66 \%$ & $0.71[0.62,0.81]$ \\
\hline Subtotal $(95 \% \mathrm{Cl})$ & 4209 & 4194 & $\boldsymbol{\nabla}$ & $94.41 \%$ & $0.74[0.67,0.82]$ \\
\hline \multicolumn{6}{|c|}{ Total events: 959 (Treatment), 1192 (Control) } \\
\hline \multicolumn{6}{|c|}{ Heterogeneity: $\mathrm{Tau}^{2}=0 ; \mathrm{Chi}^{2}=3.98, \mathrm{df}=2(\mathrm{P}=0.14) ; \mathrm{I}^{2}=49.7 \%$} \\
\hline \multicolumn{6}{|c|}{ Test for overall effect: $Z=5.92(P<0.0001)$} \\
\hline \multicolumn{6}{|l|}{ 1.3.2 Fibrates } \\
\hline VACSA 1973 & $67 / 268$ & $55 / 264$ & 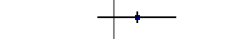 & $5.59 \%$ & $1.27[0.84,1.89]$ \\
\hline Subtotal $(95 \% \mathrm{Cl})$ & 268 & 264 & & $5.59 \%$ & $1.27[0.84,1.89]$ \\
\hline \multicolumn{6}{|c|}{ Heterogeneity: Not applicable } \\
\hline \multicolumn{6}{|c|}{ Test for overall effect: $Z=1.14(P=0.25)$} \\
\hline Total $(95 \% \mathrm{Cl})$ & 4477 & 4458 & 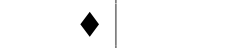 & $100 \%$ & $0.77[0.7,0.84]$ \\
\hline \multicolumn{6}{|c|}{ Total events: 1026 (Treatment), 1247 (Control) } \\
\hline \multicolumn{6}{|c|}{ Heterogeneity: $\mathrm{Tau}^{2}=0 ; \mathrm{Chi}^{2}=10.27, \mathrm{df}=3(\mathrm{P}=0.02) ; \mathrm{I}^{2}=70.79 \%$} \\
\hline \multicolumn{6}{|c|}{ Test for overall effect: $Z=5.48(P<0.0001)$} \\
\hline Test for subgroup di & $, d f=1(P=0.01), I$ & & & & \\
\hline
\end{tabular}

Analysis 1.4. Comparison 1 Intervention versus control: history of stroke or TIA, Outcome 4 Ischaemic strokes.

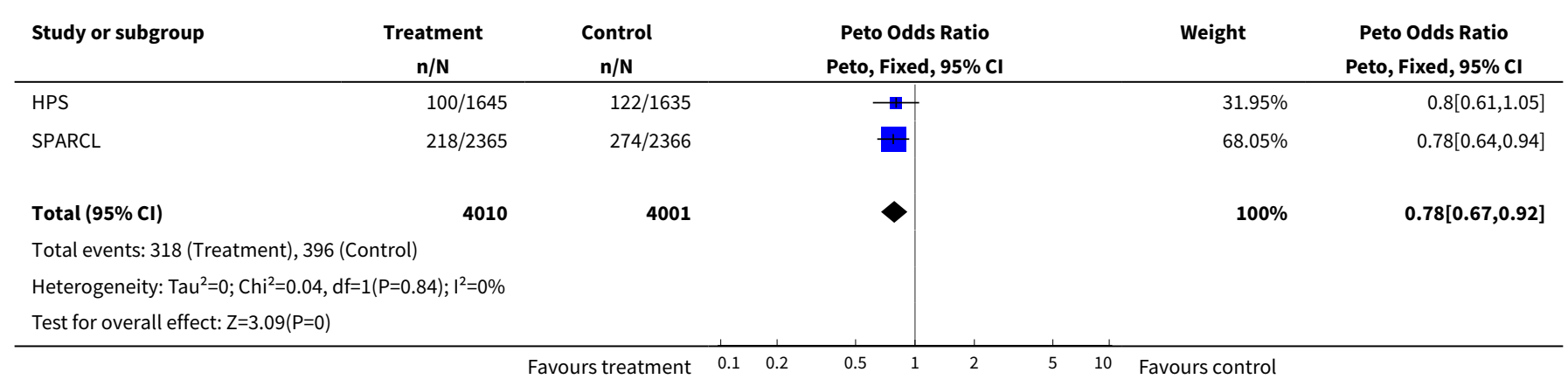


Analysis 1.5. Comparison 1 Intervention versus control: history of stroke or TIA, Outcome 5 Haemorrhagic strokes.

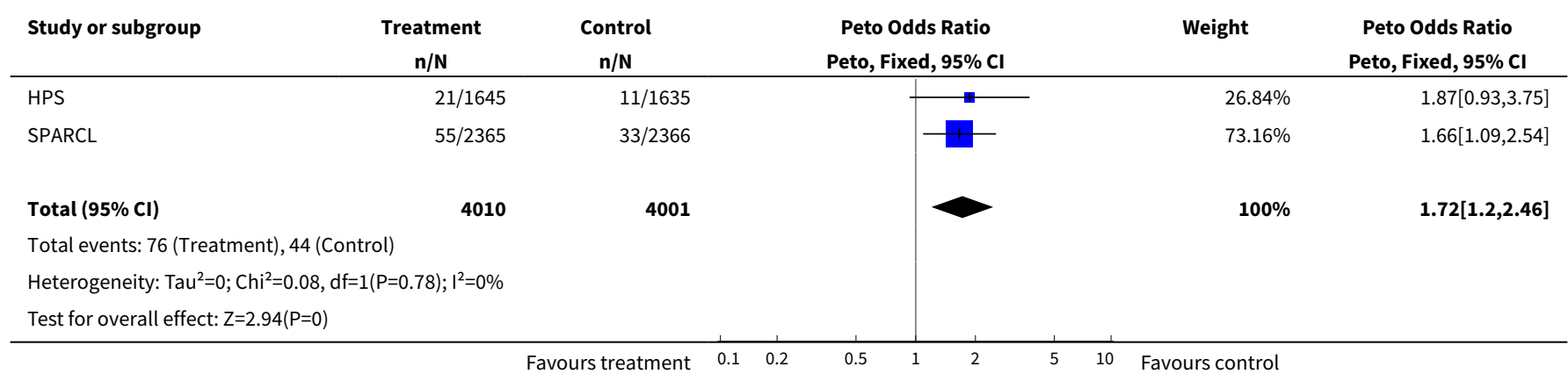

\section{Comparison 2. Intervention versus control: history of stroke}

\begin{tabular}{|c|c|c|c|c|}
\hline $\begin{array}{l}\text { Outcome or subgroup } \\
\text { title }\end{array}$ & No. of studies & $\begin{array}{l}\text { No. of partici- } \\
\text { pants }\end{array}$ & Statistical method & Effect size \\
\hline $\begin{array}{l}1 \text { All ischaemic or haem- } \\
\text { orrhagic strokes }\end{array}$ & 4 & 1558 & Peto Odds Ratio (Peto, Fixed, 95\% Cl) & $0.97[0.71,1.31]$ \\
\hline 1.1 Statins & 2 & 491 & Peto Odds Ratio (Peto, Fixed, 95\% Cl) & $0.73[0.44,1.22]$ \\
\hline 1.2 Fibrates & 1 & 485 & Peto Odds Ratio (Peto, Fixed, 95\% Cl) & $1.47[0.84,2.57]$ \\
\hline 1.3 Oestrogen & 1 & 582 & Peto Odds Ratio (Peto, Fixed, 95\% Cl) & $0.90[0.53,1.54]$ \\
\hline $\begin{array}{l}2 \text { All cause mortality, in- } \\
\text { cluding sudden deaths }\end{array}$ & 1 & 582 & Peto Odds Ratio (Peto, Fixed, 95\% Cl) & $1.16[0.69,1.95]$ \\
\hline 2.1 Oestrogen & 1 & 582 & Peto Odds Ratio (Peto, Fixed, 95\% Cl) & $1.16[0.69,1.95]$ \\
\hline 3 Serious vascular events & 1 & 582 & Peto Odds Ratio (Peto, Fixed, 95\% Cl) & $1.03[0.72,1.48]$ \\
\hline 3.1 Oestrogen & 1 & 582 & Peto Odds Ratio (Peto, Fixed, 95\% Cl) & $1.03[0.72,1.48]$ \\
\hline
\end{tabular}

Analysis 2.1. Comparison 2 Intervention versus control: history of stroke, Outcome 1 All ischaemic or haemorrhagic strokes.

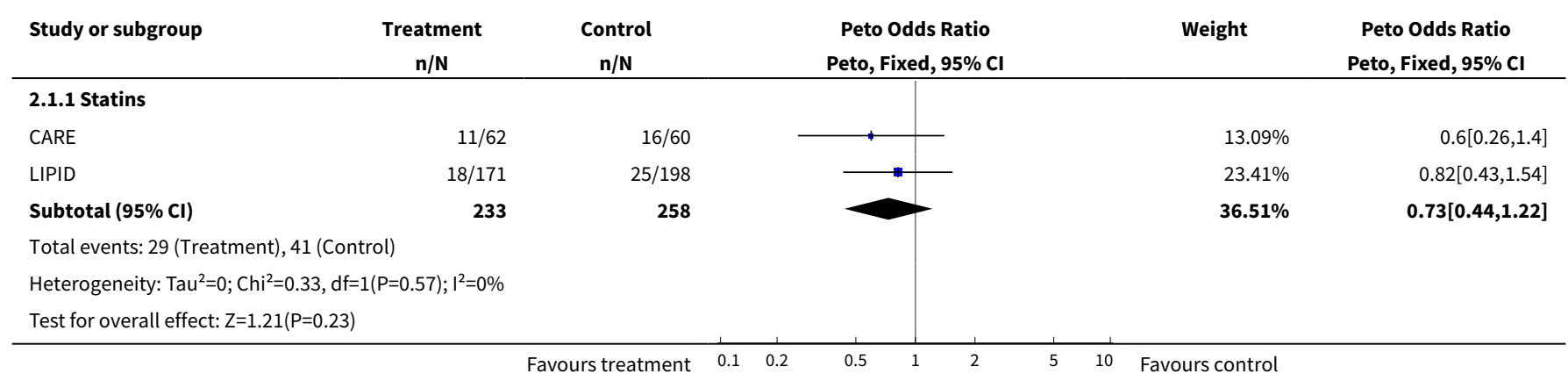




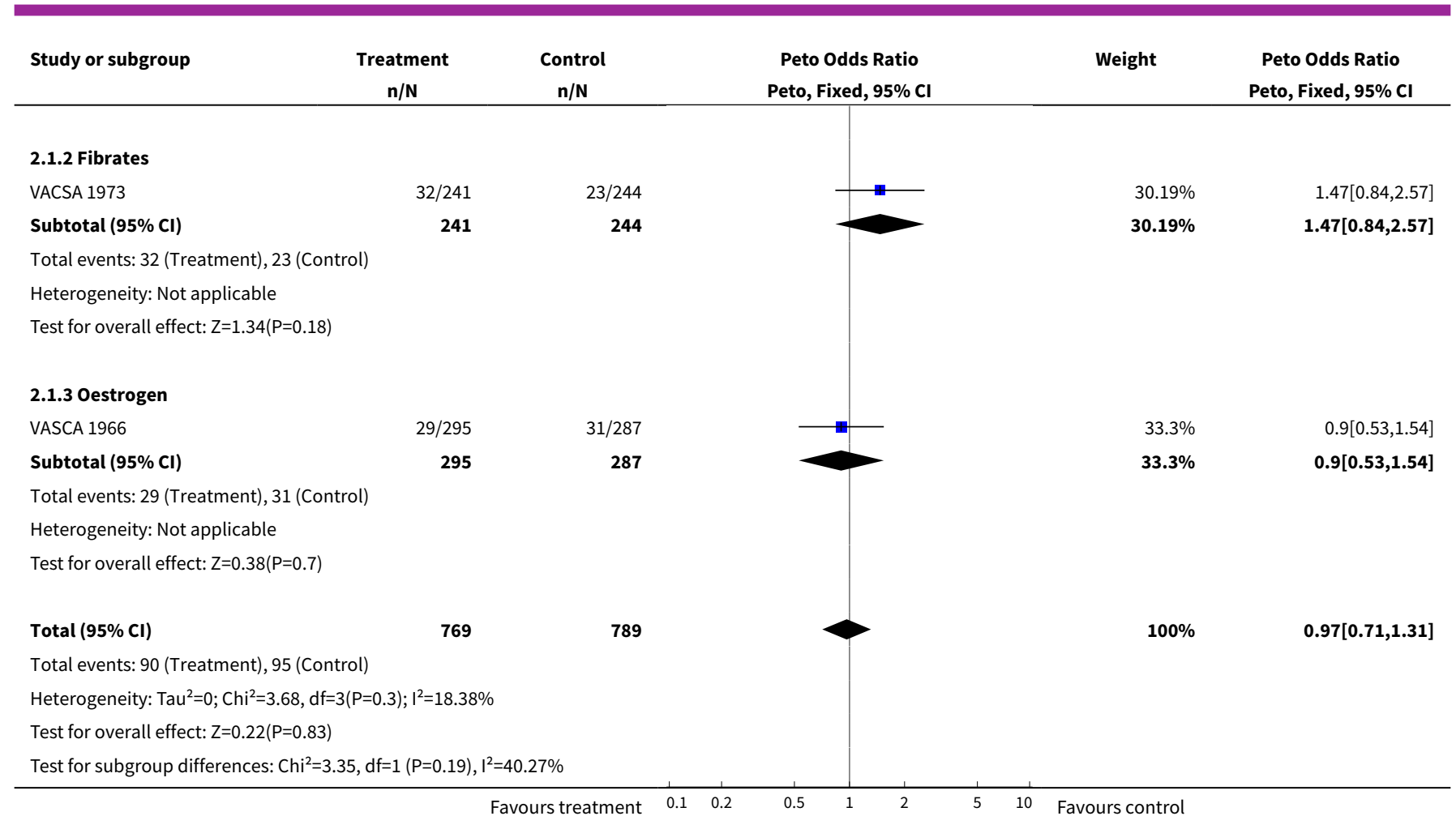

Analysis 2.2. Comparison 2 Intervention versus control: history of stroke, Outcome 2 All cause mortality, including sudden deaths.

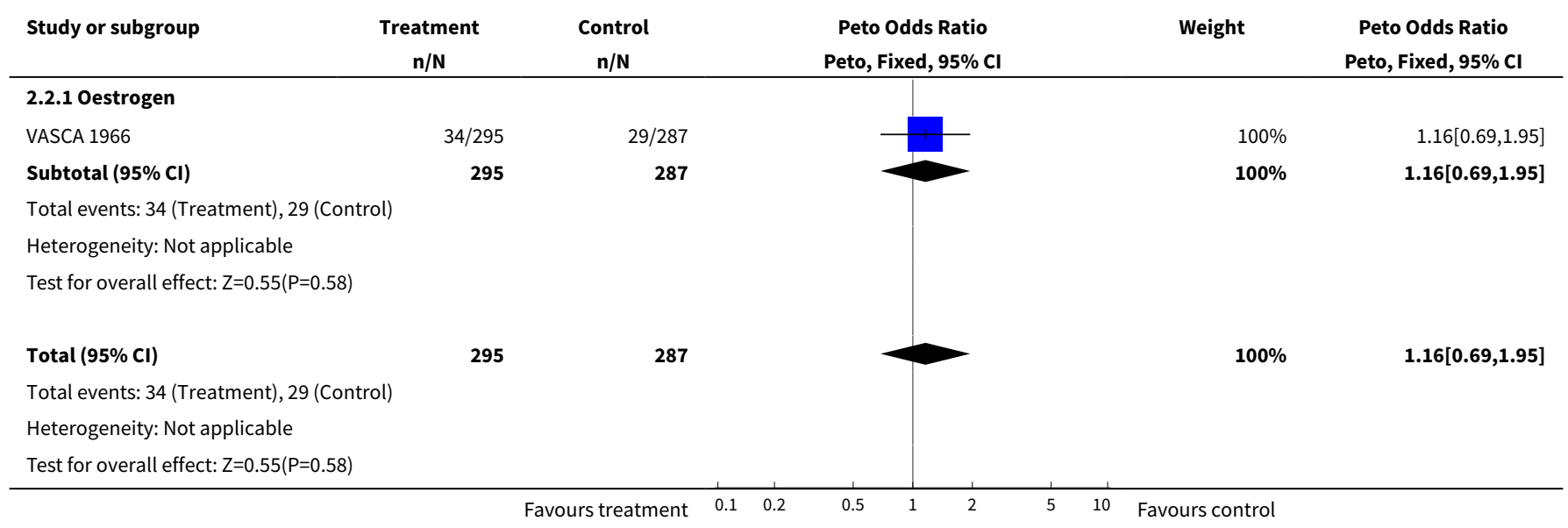

Analysis 2.3. Comparison 2 Intervention versus control: history of stroke, Outcome 3 Serious vascular events.

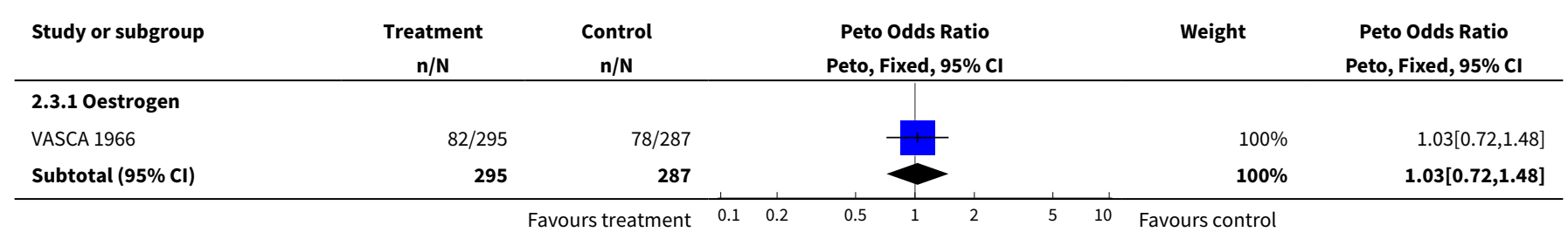




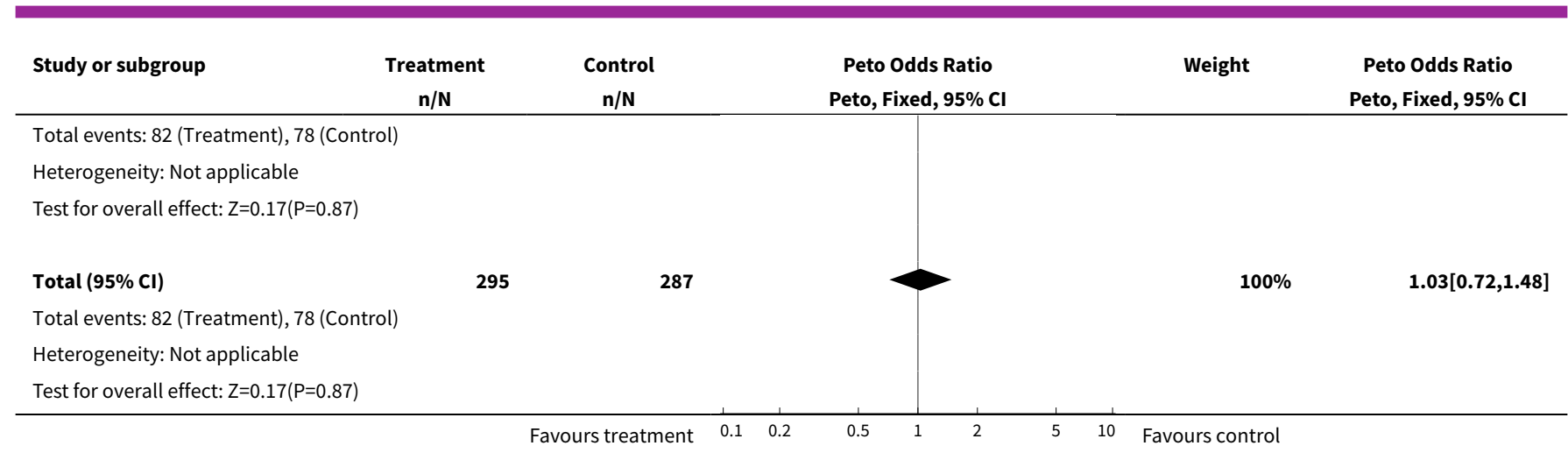

\section{AP PEN DICES}

\section{Appendix 1. MEDLINE search strategy}

1 exp Cerebrovascular disorders/

2 stroke\$.tw.

3 (cerebrovascular\$ or cerebral vascular or CVA\$).tw.

4 (cerebral or cerebellar or brain $\$$ or vertebrobasilar).tw.

5 (infarct\$ or isch?emi\$ or thrombo $\$$ or emboli\$).tw.

64 and 5

7 (cerebral or intracerebral or intracranial or parenchymal).tw.

8 (brain or intraventricular or brainstem or cerebellar).tw.

9 (infratentorial or supratentorial or subarachnoid).tw.

107 or 8 or 9

11 (haemorrhage or hemorrhage or haematoma or hematoma).tw.

12 (bleeding or aneurysm).tw.

1311 or 12

1410 and 13

15 transient isch?emic attack\$.tw.

161 or 2 or 3 or 6 or 14 or 15

17 exp Hypercholesterolemia/dt [Drug Therapy]

18 exp Hyperlipidemia/dt [Drug Therapy]

1917 or 18

20 exp Antilipemic agents/

21 exp Anion exchange resins/

22 cholestyramine.tw.

23 colestipol.tw.

2420 or 21 or 22 or 23

25 clofibrate.tw.

26 bezafibrate.tw.

27 ciprofibrate.tw.

28 fenofibrate.tw.

29 gemfibrozil.tw.

3025 or 26 or 27 or 28 or 29

31 exp Hydroxymethylglutaryl-coa reductase inhibitors/

$32 \mathrm{hmg}$-coa reductase inhibitor\$.tw.

33 atorvastatin.tw.

34 fluvastatin.tw.

35 lovastatin.tw.

36 pravastatin.tw.

37 simvastatin.tw.

38 statin\$.tw.

3931 or 32 or 33 or 34 or 35 or 36 or 37 or 38

40 exp Niacin/

41 nicotinic acid.tw. 
42 acipimox.tw.

4340 or 41 or 42

44 exp Fish oils/

45 fish oil\$.tw.

46 omega-3 marine triglycerides.tw.

47 exp Dietary fiber/

48 soluble fib\#\#.tw.

4944 or 45 or 46 or 47 or 48

5019 or 24 or 30 or 39 or 43 or 49

5116 and 50

52 limit 51 to human

53 limit 51 to animal

5452 and 53

5553 not 54

5651 not 55

\section{FEE D B A C K}

\section{Concerns regarding conclusions, 17 July 2019}

\section{Summary}

Based on our brief analysis of this review and the two main trials included (SPARCL and HPS), we are not sure if the conclusion about statin use post-stroke in this Cochrane review is supported based on the following concerns:

- The authors concluded that statin therapy in patients with a history of stroke significantly reduces subsequent major coronary events. However, major coronary events was not an outcome that was looked at in this review. Perhaps, this conclusion may have been referring to findings of other studies but it does not appear to be a direct conclusion from this review.

- The review pools the stroke outcome data from various trials, which appear to have some variance in their definition of stroke. It may be difficult to determine the exact source of the numbers extracted from the individual trials and whether they best align with the review's definition of stroke. For example, in the primary outcome of all ischemic and hemorrhagic stroke (Analysis 1.1), the definition of stroke in the HPS and SPARCL study is unclear as the incidence of stroke reported in this cochrane analysis was different from the individual sum of the ischemic plus hemorrhagic stroke rates reported in the trials. If it was the individual types of stroke summed up this may inappropriately lead to double-counting some patients who had both an ischemic and a hemorrhagic stroke.

- There may be some discrepancy between the outcomes analyzed in the review and the data the authors used from the individual trials. For example, in the SPARCL trial, any cardiovascular event was defined as "any of the former" (presumably referring to stroke or TIA, major coronary event, major cardiovascular event, any coronary event and revascularization) "plus clinically significant peripheral vascular disease." This data was used for the serious vascular event analysis (Analysis 1.3) by the cochrane review authors which they defined as non-fatal stroke, non-fatal myocardial infarction and vascular death.

- Data appears to be missing for outcome 2 All-cause mortality (Analysis 1.2) in this review. Only data from the SPARCL trial was included. The original HPS study contained all-cause mortality outcome data but this was not published for the stroke subgroup. The cochrane review authors may have benefited from contacting the study investigators for this information to provide a more comprehensive analysis of this outcome.

- It is unclear whether this review encompasses all studies regarding this topic as the results of the search strategy and reasons for excluding studies were not included.

- The risk of bias assessment should be re-evaluated and an update may be warranted to align with current cochrane review standards.

(Feedback received: 13 November 2018)

\section{Reply}

None received

\section{Contributors}

Andrea Feere, Anthony Lau, Jenny Wang, Aaron M Tejani

\section{WHAT'S NEW}

\begin{tabular}{lll}
\hline Date & Event & Description \\
\hline 17 July 2019 & Feedback has been incorporated & Feedback incorporated \\
\hline \hline
\end{tabular}




\section{HISTORY}

Protocol first published: Issue 2, 2000

Review first published: Issue 3, 2002

\begin{tabular}{lll}
\hline Date & Event & Description \\
\hline 17 December 2008 & New search has been performed & $\begin{array}{l}\text { The literature searches have been updated to December 2008 } \\
\text { and three new trials have been included, giving a total of eight } \\
\text { included studies involving approximately 10,000 participants. }\end{array}$ \\
\hline 17 December 2008 & $\begin{array}{l}\text { New citation required and conclusions } \\
\text { have changed }\end{array}$ & $\begin{array}{l}\text { With the addition of three included studies (FASTER; HPS; SPAR- } \\
\text { CL), there is now evidence of a reduction in subsequent serious } \\
\text { vascular events from statin therapy in patients with a history of } \\
\text { ischaemic stroke or transient ischaemic attack. }\end{array}$ \\
\hline 27 August 2008 & Amended & Converted to new review format. \\
\hline
\end{tabular}

\section{CONTRIBUTIONS OFAUTHORS}

BN Manktelow: writing of review, literature search, data extraction, data analysis. JF Potter: writing of review, data extraction.

\section{DECLARATIONS OF INTEREST}

JF Potter has received honoraria from MSD, Sanofi and Boehringer Ingelheim for attending Advisory Boards or giving lectures at meetings sponsored by these companies.

\section{N DEX TERMS}

\section{Medical Subject Headings (MeSH)}

Cause of Death; Coronary Disease [prevention \& control]; Hypercholesterolemia [ ${ }^{\star}$ drug therapy]; Hypolipidemic Agents [ ${ }^{\star}$ therapeutic use]; Ischemic Attack, Transient [complications]; Randomized Controlled Trials as Topic; Secondary Prevention; Stroke [ ${ }^{\star}$ prevention \& control]

\section{MeSH check words}

Humans 